\title{
Editorial: Past, present and future ice core research
}

Ice core science is still a young field of paleoclimatic and atmospheric research. Essentially, it all began in the 1960s when American, Danish and Swiss researchers retrieved the first deep ice core record from Camp Century, northwestern Greenland. From that point on, it has been a success story, with many national and international deep ice core projects changing our view of the Earth's climate system. The documentation of unprecedented rapid climate variations in Greenland ice cores during the last glacial (Dansgaard-Oeschger events, named after two pioneers in ice core research), and the quantitative reconstruction of greenhouse gas concentrations from air bubbles enclosed in the ice, are just two of the most striking examples of how ice core science has advanced our knowledge.

The success of ice cores alongside other outstanding paleoclimatic archives, such as marine and lake sediments, tree rings, corals, etc., stems from their high temporal resolution combined with their coverage of many glacial cycles. In addition, the combination of various climatological and atmospheric data streams (temperature, gases, aerosols, etc.) from the same independently dated archive make ice cores extremely valuable.

Despite its rather short history, ice core science has gained huge momentum and had a very strong impact on paleoclimatology. It

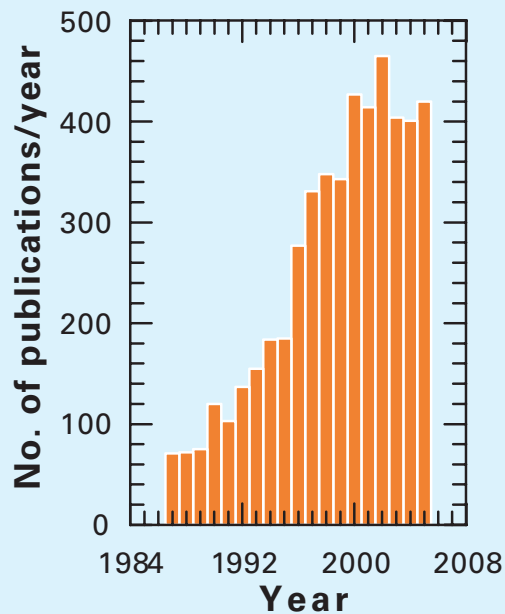

Figure: Publication history of papers with the keyword "ice core" from 1987-2005. Information was retrieved from SCOPUS (www.scopus.com/scopus/home.url). has reached full speed only within the last decade, as reflected by the extraordinary development of the publication history of ice core related papers (see Figure), which have experienced a six-fold increase in the last 15 years, and by the rapid multiplication of ice core drilling projects in different regions of the globe, bringing new national players such as China, Korea and India into the game.

High time to bring together the most important results gained from various research groups worldwide and to think about the future. Accordingly, this issue of PAGES News gives an overview of the results of many of the major ongoing ice core projects, reaching spatially from the poles to the equator and temporally from recent climate variability to paleoclimatology over the last 800,000 years. The need to look ahead and shape the future of ice core science in multinational collaborations has long been recognized. In the last two years, this has led to the "International Partnerships in Ice Core Sciences (IPICS)", an open planning body of currently 18 nations that has identified the most important scientific questions to be addressed in future ice core projects. These questions have been channeled into four IPICS white papers (www.pages-igbp. org/science/initiatives/ipics/), which are also summarized in this issue of PAGES news. The timing of this newsletter is also fitting, considering the upcoming International PolarYear (IPY). IPY will be the starting line for many of these future ice core projects, which will keep us glaciologists busy for another 10-20 years, and will provide the paleoclimate community with more detailed, quantitative and potentially paradigm-changing ice core results.

HuBERTUS FISCHER

PAGES Guest Editor

Alfred-Wegener-Institute for Polar and Marine

Research, Bremerhaven, Germany

hufischer@awi-bremerhaven.de

\section{PAGES newsletters: Would you prefer a digital copy?}

\section{Digital Newsletter}

PAGES News is also available electronically. If you subscribe to the digital newsletter, we will send you an email each time a new issue is published, with the link to the website where you can download a low- or highresolution Acrobat pdf. If you would like to sign up for the digital version, please send an email to Leah Christen (christen@pages.unibe.ch).

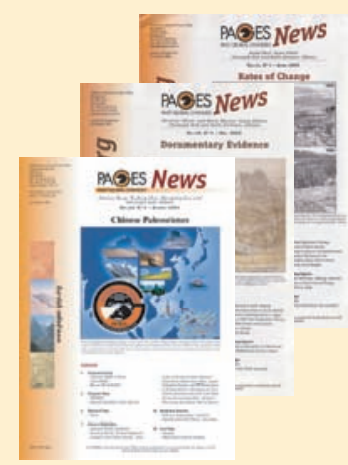

